\title{
Ulusal Güvenlik Politikası Çerçevesinde ABD'nin Güvenlik Anlayışına Kronolojik Bir Bakış
}

\author{
DOI: 10.26466/opus.629941
}

\author{
*

\begin{abstract}
Onur Gündüz* - Volkan Göçoğlu**
* Doktora Öğr., Polis Akademisi, Güvenlik Bilimleri Enstitüsü, Güvenlik Stratejileri ve Yönetimi Doktora Programı, Ankara/Türkiye E-Posta: gunduzonur54@gmail.com

ORCID: 0000-0003-4280-531X

** Dr. Öğr. Üy., Afyon Kocatepe Üni., Dinar Uygulamalı Bilimler Y.O, Dinar/ Afyonkarahisar E-Posta: volkangocoglu@gmail.com

ORCID: $\underline{0000-0002-7036-2416}$
\end{abstract}

\section{Öz}

Bu çalışmada, kuruluşundan bugüne kadar ABD'nin güvenlik stratejilerinin geçirdiği evrim ulusal güvenlik politikası temelinde ele alınmıştır. Kuruluş döneminde ABD'nin kendi felsefesi ile paralel olarak gelişen güvenlik algısı incelenirken, Birinci Dünya Savaşı, İkinci Dünya Savaşı ve devamında oluşan gelişmelerin, ABD'nin güvenlik anlayışın Avrupa'ya ve diğer ülkelere müdahil olmaya nasıl ittiği anlatılmıştır. Çalışmada, ABD'nin kimliğinin şekillenmesinde çok büyük bir etkisi olan Soğuk Savaş dönemine değinildikten sonra 1990'lı yıllar ele alınmış, ardından ABD'nin güvenlik anlayışını bugüne getiren ve bir milat kabul edilen 11 Eylül saldırıları ve bu saldırlara gösterilen reaksiyon irdelenmiştir. Başkan Bush ve Başkan Obama dönemleri sonrası Başkan Trump döneminin güvenlik algısının ele alındığ̆ çalışmada, ABD siyasetinde 11 Eylül olayları güvenlik anlayışı açısından nasıl bir milat ise, Trump dönemi etkin anlayışının da bu noktada bir başka milat olduğu ortaya konulmuştur. Geniş kapsamlı bir literatür taraması yapılıp çeşitli kaynaklardan ikincil verilere yer verilirken, dönemlerin güvenlik anlayışlarına etki eden düşünce ve olaylar da yorumsamacı bir bakış açısıyla ele alınmıştır.

Anahtar Kelimeler: ABD Ulusal Güvenlik Stratejisi; Dönemler; Güvenlik Politikast; Değişen Güvenlik Konsepti 


\title{
A Chronological Perspective on US Security Approach within the Framework of National Security Policy
}

\begin{abstract}
In this study, the evolution of US security strategies since its foundation is discussed on the basis of national security policy. While examining the perception of security that developed in parallel with the US's own philosophy during the establishment period, it was explained how the world formed during the First World War, the Second World War and the aftermath of the United States pushed the security understanding of the USA to Europe and the rest of the world. After mentioning the Cold War period, which had a great impact on shaping the identity of the USA, the 1990s were explained and the September 11 attacks, which brought the US security understanding to today and accepted as a milestone, and the reaction to these attacks were explained. In the study, which describes the security perception of the Trump period after the President Bush and President Obama periods, it is revealed that the September 11 events are another milestone in terms of security understanding in US politics, and the effective understanding of the Trump era is another milestone. In this study, a comprehensive literature review was conducted, while secondary data from various sources were included, and thoughts and events affecting the security perceptions of the periods were handled with an interpretative perspective.
\end{abstract}

Keywords: USA National Security Strategies, Periods, Security Policy, Changing Concept of Security 


\section{Giriş}

Karşılaştırmalı ülke incelemeleri çalışmalarında, ülkelerin iktisadi, siyasi, sosyal sistemleri ve politikalarını başta olmak üzere çeşitli politikaları, gerek Türkiye'ye birer iyi/kötü örnek oluşturması açısından, gerekse Türkiye ile lişkilerinin bu boyutlarda analiz edilmesi açısından incelenmektedir. Ülkelerin güvenlik politikaları da bu anlamda incelenmesi, irdelenmesi ve kavranması son derece önemli olan politikalardır. Zira güvenlik politikaları bir ülkenin bekası ile birincil derecede ilgili politikalarıdr. Her ne kadar bu politikalarla ilgili tam ve mutlak bilgiye, yargıya ve çıarsamaya varmak zor olsa da (Avaner ve Çiner, 2019, s.v) farklı ülkelerin güvenlik politikalarını irdelemek ve anlamak, ülkelerin Türkiye ile bu boyutlardaki ilişkilerini, tarihsel etkileşimlerini ve içinde bulunulan dönemdeki pozisyonlarını anlamak için de elzemdir.

Ulusal güvenlik politikası, devletlerin ulusal güvenliklerini sağlamak ve milli çıarlarını korumak amacıyla ellerinde bulunan sivil ve askeri kaynaklarını, savunma ve saldırı unsurlarını belirli bir ölçüde ya da topyekûn, ancak koordineli bir şekilde kullanmasını ifade etmektedir. Gohlert (1974, s.174), ülkelerin güvenlik politikalarını iki bakış açısı etrafında oluşturduklarını ileri sürmektedir. Buna göre ülkeler, ilk olarak hayati unsurlarını korumayı amaçlarlar. Bunun için diplomasi, müzakere, uzlaşma gibi seçeneklerden ziyade, mevcut askeri gücün ve kaynakların kullanılmasını öncelikli tutarlar. İkinci bakış açısında ise hayati olmayan ve dış politika, müzakere ve uzlaşma gibi süreçlerle yönetilen ve yönlendirilen bir güvenlik politikası bulunmaktadır. Gohlert (1974), ulusal güvenlik politikası üzerinde yürütülen bir tartışmaya dikkat çekmektedir. Bu tartışmaya göre iki farklı bakış açısı bulunmaktadır. Wolfers'in ortaya koyduğu birinci bakış açısına göre ulusal güvenlik politikaları ülkelerin önceden kazanılmış bir takım değerlerine karşı tehdit ya da saldırı kaygısından beslenmektedir. İkinci bakış açısında ise Rosenau, ulusal güvenliğin sadece bir tehdit ya da kaygıdan kaynaklanmaktan ziyade ulusların arasında, birbirlerine karşı sergilenen tavırlar etrafında şekillenen ve planlanmış hamlelerin gerçekleştirildiği etkileşimli bir süreç olarak ele almaktadır (Gohlert, 1974, s.175). Bu tartışmaya değinen yazar, ulusal güvenliğin kaynağını sorgulamak için "Neyin güvenliği ve ne için?" sorusunu sormaktadır. Belki de soruda eksik kalan ve güvenlik 
politikasının niceliğine değinecek "Nasıl bir güvenlik?" sorusu için ise Lehman ve Willet (1986)'in ABD'nin güvenlik politikasının kaynaklarını ve yönelimlerini ele aldıkları çalışmalarına değinmek gerekmektedir. Yazarlara göre ABD'nin güvenlik politikası iki ana konu üzerinde şekillenmektedir. Bunların ilkinde ülkenin liberal ekonomik yapısı ve anlayışının etkisi büyüktür. Buradaki birinci konu, ulusal güvenlik politikası çerçevesinde atılacak adımlarda devlet ve özel sektörün karşı karşıya geldiği ve uyuşmadığı noktalardır. Örneğin, devlet yeni bir politika için farklı alanlarda araştırma ve geliştirme yapılmasını bir politika olarak belirleyebilir. Bu alanda yapılacak araştırma ve geliştirme için yapılacak finansal yatırımlar ise özel sektör için henüz ölü yatırımlar olabilir ve özel sektör bu durumda yatırım konusunda isteksiz olacaktır. İkinci konu ise ulusal güvenlik politikasında var olan aktörlerin amaçlara daha iyi ulaşmak adına teşvik edilmesidir. Bu aktörler devlet kurumları, özel sektör kurumları, sivil toplum kuruluşları ve bireysel düzeyde ise vatandaşlardır. Görüldügü üzere ulusal güvenlik politikası hem tanımıyla hem de sahip olduğu içerikle, çok boyutlu bir kavramı ifade etmektedir. Özellikle 20. yüzyılın sonlarına gelindiğinde ise, ABD'deki liberal anlayışın etrafında şekillenerek tüm dünyaya yayılan küreselleşme olgusu ve süreci ile birlikte ulusal güvenlik kavramı yeni bir boyut kazanmıştır. Yeni boyutta ulusal güvenliğin ülkelerin sinırlarına ve toprak bütünlüklerine yaptığı vurgu azalmıştır. Zira küreselleşme ve teknolojik gelişmeler ile birlikte devletlerin fiziki sınırları, özellikle ticaret ve güvenlik (siber güvenliğin ortaya çıkışı ile birlikte) boyutlarında önemsizleşmeye ve belirginliğini yitirmeye başlamıştır (Göçoğlu, 2018, s.69).

Çalışmanın odak aldığı ülke olan ABD'nin güvenlik algısı ve politikasına giriş mahiyetinde, ülkenin güvenlik algısını kısaca özetleyecek olursak, ülke, Avrupa ülkelerinden göç alarak, İngiltere'nin kolonilerinin birleşmesi ve daha sonra da bağımsızlığını ilan etmesi ile kurulmuştur. Göçlerin altında pek çok neden yatmakla beraber esas olarak yeni bir yaşam kurma (toprak kazanma, koloni kurma, sömürgecilik vb.) ve Hristiyan kiliselerinin baskılarından kaçma gibi nedenler göze çarpmaktadır. Göç eden grupların ağırlıklı olarak Hristiyan (protestan) ve Liberal bakış açısına sahip olması, ABD'nin tarihinden bugüne kadar devletin her bir kurumunun yapısını etkilediği gibi (bkz. Eroğlu, 2016), güvenlik algısını 
ve dolayısıyla da güvenlik politikalarını şekillendirmiştir. Avrupa devletlerinin aksine ABD kurulduğu coğrafya sebebiyle muazzam kaynaklara ve büyük miktarda boş araziye sahipti. Bu durum ABD'nin gelişiminin daha hızlı olmasına imkan tanımıştı. ABD askeri güvenliği de Avrupa ile birlikte gelişmiş hem ondan etkilenen hem de onu etkileyen bir seyir izlemiştir. Bunda, sanayi ile birlikte gelişen savaş ve mühimmat endüstrisi de önemli rol oynamıştır (COMH, 1989, s.1). Gelişen devlet önce kendi yakın çevresine, daha sonra ise gerek askeri ve ekonomik anlamda gerekse kültürel manada dünyaya yayılmaya başlamıştır. Bunda şüphesiz dünyanın durumunun, yaşanılan büyük savaşların ve sermaye akışının da etkisi vardır. Ancak özellikle Soğuk Savaş sonrası dönemde dünyanın tek başına hakimi ve sahibi gibi davranan ABD (Lind, 2006, s.110-124), karşısına farklı güçlerin çıkmasıyla ve değişen tehdit algısının da etkisiyle her geçen gün daha saldırgan bir politika izlemeye başlamıştır. Bu ana hatlar doğrultusunda çalışma, "ABD'nin güvenlik anlayışı yıllar içerisinde nasıl şekillenmiştir?" araştırma sorusuna yanıt aramaktadır. Yanıta ulaşmak için çalışmada özellikle literatür taraması temelinde ikincil verilerden yararlanılmıştır. Ulaşılan kaynaklardan elde edilen bilgiler kronolojik olarak işlenmiş ve yorumlanmıştır. Ülkenin güvenlik yönelimleri, Kuruluş Dönemi, I. Dünya Savaşı ve II. Dünya Savaşı Dönemi, Soğuk Savaş Dönemi, 1990'lı Yıllar, 11 Eylül ve Sonrası, 2006 Yılı ve sonrası olmak üzere altı dönemde ele alınmıştır.

\section{Kuruluş Döneminde ABD’nin Milli Güvenlik Stratejisi}

Temeli Protestanlık ilkeleri ile aydınlanmanın demokratik değerleri olan ABD, özellikle de güvenlik politikaları anlamında liberalizmle beraber Hristiyanlık ve Yahudilikten etkilenmiştir (Arslan ve Arı, 2004, s.16-46; Fischer, 2005, s.152). Amerikan Bağımsızlık Bildirisi ABD'nin eşitlik temelinde bir anlayış güderek, bu bakış açısıyla hareket etmesine vesile olmuştur. Ancak Avrupa'da savaşların başlamasıyla bahsi geçen anlayış zamanla değişmeye başlamıştır (Kissenger, 2000, s.17). Anti-kolonyal bir tutum sergileyen ve ABD'nin Avrupa'nın işlerine karışmayacağını, kabuğuna çekilmeci bir anlayış sergileyeceğini deklare eden Monroe Doktrini ve ilerleme arzusunun kendi kıtası ile sınırlı olduğunu dolaylı olarak 
ifade eden Manifest Destiny (Açık Kader) ile kendi bulunduğu kıta içerisinde yayılan ABD, kesin olarak siyasi anlamda Avrupa ile ayrıştığını ilan etmiştir.

Oluşan yeni ulusal güvenlik anlayışı ve politikasına göre Amerika kıtası, Avrupa'nın sömürgesi olmayacak ve herhangi bir müdahale ABD tarafından kendi barış ve güvenliğine bir tehdit olarak görülecektir. Ayrıca ABD bu doktrin ile kendini Amerika kıtasının da lideri olarak gördügünü göstermiş ve gerektiğinde kıta içerisinde müdahale araçlarını da kullanacağını da ilan etmiştir (Armaoğlu, 2010, s.996; Toman ve Akman, 2014, s.285). Toprak satın alınması suretiyle veya savaş yoluyla sınırlarını genişleten $\mathrm{ABD}$ ilerleyen yıllarda farklı müdahale araçları ile güvenliğini koruma yoluna gitmiştir (Keskin, 2016, s.71). Böylece ABD, bağımsızlığını ve gücünü pekiştirerek kendisinden başka bir gücü kabul etmediğini göstermektedir.

\section{Birinci Dünya Savaşı Dönemi}

1900'lü yıllar ABD'nin güvenlik anlayışının değişerek Theodore Roosevelt'in tabiri ile "yumuşak konuş ve büyük bir sopa taşı" şeklinde ifade ettiği daha cüretkar bir hal almasına sahne olmuştur (Akçay ve Akbal, 2013, s.17). Bunda şüphesiz ABD'nin deniz gücünün ve deniz ticareti lobisinin etkisinin artması ile bir paralellik vardır. Roosevelt döneminde donanma bütçesinin genel bütçedeki payı \%9.2 artırılarak \%20.7'ye yükseltilmiştir (Ateş, 2004, s.98). Aynı dönemde ABD'de Genel Kurmay Başkanlığı kurulmuştur. Roosevelt'in inancı ABD'nin bölgenin jandarması konumuna gelmesi ve başkanın etkinliğinin artırılmasının sağlanması şeklindedir. Böylelikle Monroe Doktrininin esasları bir yana bırakılarak daha saldırgan bir anlayış benimsenmeye başlanmıştır (Sümer, 2008, s.126).

Roosevelt Panama'nın Kolombiya'dan koparak bağımsız olmasına destek vermiş, daha sonra da Panama Kanalı'nı ele geçirmiştir. Aynı dönemde silahlanma da teşvik edilmiştir (Kissinger, 2000, s.24). Almanya'nın askeri anlamda güçlenmesi de aynı döneme denk gelmektedir (Ateş, 2004, s.100). Salt liberal ekonomi anlayışının zararlı yanlarını törpülemek adına sosyal programlara da yer veren "New Deal" ekonomik 
programı, ABD'de yine aynı dönemde uygulanmıştır. Uygulanan politikalar ABD'nin yalnız kalmasına sebep olmakla kalmamış aynı zamanda da güçsüzleşmesine kapı açmıştır (Nevins ve Commager, 2014, s.487-486).

Wilson dönemi ABD'nin Nikaragua, Haiti ve Meksika'ya askeri müdahaleler yaptığı dönemdir. Bu dönemde ABD'nin diş politika anlayışında değişmeler olmuştur. Ancak Avrupa'nın bozulan mali durumu ABD'yi de etkilemiştir. 1929 bunalımı ile beraber ABD'nin ekonomik istikrarının Avrupa'nın ekonomik düzeninden ayrı düşünülmeyeceği görülmüştür. Karşılıklı ekonomik bağımlılık, siyasi bağımlılığı da beraberinde getirmiştir. Başkan Wilson Milletler Cemiyetine girerek daha aktif bir siyaset izlemek istemiştir ancak başkanin bu isteğine rağmen ABD'nin Milletler Cemiyetine girmesi mümkün olmamıştır (Sümer, 2008, s.127). Bu dönem Wilson'un 14 prensibinin esas alındığı yenilikçi bir dönemdir. Zaten Milletler Cemiyeti'nin kurulmasının ardındaki paradigma da budur. Ancak Milletler Cemiyeti'nin kuruluşu ABD senatosunda kabul edilmemiştir. Dolayısıyla ABD sürece aktif olarak dahil olamamıştır (Nevins ve Commager 2014, s.378).

1920 - 1925 tarihleri arasında Versay Antlaşması'na rağmen silahlanmaya başlayan Almanya, ilerleyen dönemde de pek çok yatırım yaparak ayağa kalkmıştır. Güçlenen Almanya Avrupa'da pek çok ülkeye saldırmış, ardından Sovyetler Birliği ile savaşa tutuşmuştur. Fransa işgal edilirken tarafsız kalan ABD, savaşa İngiltere'nin de dahil olması durumunda yaşanabilecekler üzerinden çeşitli hesaplar yapmıştır. Franklin Roosevelt'in tekrar iktidara gelmesi ile ABD, Avrupa'da ortaya çıkan gelişmelere paralel olarak çeşitli kanunlar çıkartmıştır. Çıkartılan yasalar, diğer devletlere askeri araç yardımını ve kiralanmasını mümkün hale getirmiştir (Nevins ve Commager, 2014, s.404). Bir diğer konu Atlantik Okyanusunda ABD'nin Alman gemilerini vurmaya başlamasıdır. Bu durum aslında fiili olarak ABD'nin savaşa girmesinin önünü açmış (Dabanlı, 2007, s.60) ve ABD kendisini savaşın içersinde bulmuştur.

\section{İkinci Dünya Savaşı Dönemi}

2. Dünya Savaşına girmek konusunda isteksiz olan ABD, Almanya'nın savaştan galip ayrılması durumunda Pasifik okyanusunda etkinliğini 
kaybedeceğinin farkındaydı. Bu durum ABD'yi müttefik devletlere yaklaştırıyordu. Müttefiklere askeri yardım yapan ABD'nin Pearl Harbour'da baskına uğraması, savaşa fiili olarak dahil olmasına sebep olmuştur. 1943 yılında ABD, pasifik okyanusunda Japon ilerleyişini durdurmuştur. Bu dönem ABD'nin küresel anlamda yaşanan olaylarda seyirci rolünü bırakarak aktif bir şekilde müdahil olma stratejisi izlediği dönemdir (Uçarol, 2004, s.796-797; Dabanll, 2007, s.60).

Ancak Savaş sonrası dönemde Başkan Franklin Roosevelt, Birleşmiş Milletler ve Marshall Planı vasıtasıyla yeni bir düzen oluşturmaya çalışmıştır. $\mathrm{O}$ dönemde hakim olan mantık, $\mathrm{ABD}$ 'nin gücünün Avrupa'nın ekonomisine bağlı olduğu şeklindedir. ABD'nin duruma müdahil olmasında şüphesiz Avrupa'daki güç boşluğunun da etkisi vardır. Küresel iyilikseverlik olarak adlandırılan ve demokratlar tarafından savunulan bu politik akım, bölge halklarının çıkarlarının da hesaba katılarak sosyo-ekonomik enstrümanların kullanılmasını ifade etmektedir (Sümer, 2008, s.128).

Savaştan galip ayrilan müttefik devletler ve Sovyetler Birliği, Avrupa'da tampon bir bölge oluşturulması konusunda istekli olmuşlardır. Sovyetlerin gücüne karşılık olarak ABD birliklerinin Avrupa'da bulunması yine müttefik devletlerin bir başka isteğidir (Dabanll, 2007, s.60).

ABD, İngiltere, Çin ve Sovyetler Birliği, ABD'nin Milletler Cemiyeti benzeri bir yapı oluşturmak için bir fırsat olarak gördüğ̈ Tahran toplantısında bir araya gelmiştir. Ancak Sovyetler Birliği bu fikri benimsememiştir. Daha sonra Yalta'da benzer bir konferans yapılmıştır. Bu konferansta Kurtarılmış Avrupa Ortak Bölgesi'nin oluşturulması karara bağlanmıştır. Bu yapı Birleşmiş Milletler için de bir başlangıçtır (Dabanlı, 2007, s.61-62).

Başkan Roosevelt'e göre Yalta Konferansı, yeni bir güvenlik paradigmasının dışa vurumudur. Roosevelt'in meseleye bakışı, bütün ulusların katılabileceği, barışın tesis edilmesinde aktif rol alacak bir kurum oluşturulması, tek taraflı sistemlerin başarısızlığının yarattı̆̆1 eksiklikleri giderme konusunda son derece yararlı olacağı şeklindedir (Kissinger, 2000, s.386). Sürecin devaminda Berlin'de bir araya gelen ABD, Sovyetler Birliği ve İngiltere, dünyanın yeni sisteminin şekillenmesi konusunda 
çeşitli görüşmeler yapmıştır. Sovyetler Birliği'nin Almanya'da güçlenmesi, Avrupa güvenliğini tehdit etmekteydi. İngiltere ise $A B D$ ve Sovyetler Birliği'ni birbiri ile dengede tutmaya çalışmaktaydı. Roosevelt'in yerine yönetime gelen Başkan Truman, dayanışmanın temel alındığı bir güvenlik konsepti ile meselelere yaklaşmıştır. Sovyetler Birliği ise yayılmacı bir anlayışla paralel olarak toprak talebi ile öne çımaktadır (Sander, 1995, s.185-194). Tarafların imzaladığı anlaşma ile Almanya dört bölgeye ayrılmıştır. Sovyetler Birliği'nin Doğu Avrupa'da yayılması devam ederken ABD'nin iç siyasetinde ise Avrupa'nın yeterince güvenceye alınmadığı konusunda Roosevelt yönetimi eleştirilmiştir (Rosenberg ve Rosenberg, 1987, s.7-8). İkinci Dünya Savaşı Avrupa için bir yıkım olmuştur. Bu dönemde ABD yardımları ile Avrupa ayağa kaldırılmaya çalışılmıştır. Kendi çıkarları için çalışan ABD, Kanada ve bazı Avrupa devletleri ile yapmış olduğu saldırmazlık anlaşmasını sonlandırmıştır. Sovyetler Birliği'nin atom bombası denemeleri de bu döneme denk gelmiştir (Schulzinger, 1990, s.201). Bu dönemde ABD'nin dış politikası daha çok diğer ülkelere müdahale etmek doğrultusunda gelişmiştir.

\section{Soğuk Savaş Dönemi}

1945-1953 yılları arasında görev yapan ABD başkanı Truman daha aktif bir politika izleyerek Sovyetler Birliğinin yayılmasını durdurmaya çalışmıştır. Bu dönemde "çevreleme politikası" uygulanmaya başlanmış ve 45 yıl kadar bu politika devam etmiştir (Şişman, 2015, s.41). Sovyetler Birliğinin taahhüt ettiğinin aksine İran'dan askerlerini çekmemesi ve Türkiye'de ki boğazlarda hakimiyet kurmak için baskı yapması, ABD'nin Sovyetler Birliği'ne karşı daha dikkatli davranmasına sebep olmuştur. Bu dönemde Berlin'in iki bölgeye ayrılması kararlaştırılmıştır (Hastedt, 1991, s.48-49; Ganley, Lyons ve Sewall, 1945, s.9). Bu gelişmeler ışı̆̆ında Yunanistan'ı ve Türkiye'yi müttefik olarak görmek isteyen başkan Truman, komünizme karşı bu ülkelere maddi yardım yapılması konusunda kongreden yetki istemiştir. Başkan Truman'ın Kongre'de yaptığı bu konuşma daha sonra Truman Doktrini olarak anılacaktır. Yunanistan'a özellikle askeri anlamda kendisini geliştirebilmesi için maddi yardım yapmanın öneminden bahseden Truman, Türkiye'nin de öneminden bahsetmiştir. Başkan Truman bu konuşmanın sonrasında Kongre'den yetkiyi alarak 
maddi yardımın yanı sıra bahsi geçen ülkelere askeri uzmanlar da gönderilmesini sağlamıştır (Erhan, 2002, s.528-529; Sönmezoğlu, 2004: 38). Ayrıca ilerleyen dönemlerde ABD, Marshall Planı çerçevesinde 16 Avrupa ülkesine 20 milyon dolar yardım yapmayı amaçlayarak Avrupa Ekonomik İşbirliği'nin de temellerini atmıştır (Billington, 1961, s.224). 1949 yılında Kuzey Atlantik İttifakı Anlaşması ABD, Danimarka, Hollanda, İtalya İzlanda, Fransa, Danimarka, Lüksemburg, Belçika, İngiltere, İzlanda, Portekiz ve Norveç'in katılımıyla imzalanmıştır (Acar, 1991, s.132-141). Sürece paralel olarak dahili önlemler de alan ABD, 1947 yılında Ulusal Güvenlik Yasası'nı çıkarmış ve Sovyetler Birliği'ni Ulusal Güvenlik Konseyi'nin 68. kararı ile çevreleme kararı almıştır. Artık çevreleme politikası ABD'nin resmi politikasıdır (Özdemir, 2003, s.2-3).

1950 yılında Kuzey Kore'nin Güney Kore'ye saldırması sonucu Birleşmiş Milletler Güvenlik Konseyi'nin verdiği yetki ile ABD savaşa müdahale hakkı elde etmiştir. Toplamda 17 ülke birleşerek Kore'ye müdahale etmiş, ardından ise Türkiye'nin NATO'ya alınması sağlanmıştır (Dabanlı, 2007, s.66). ABD, Sovyetler Birliği'nin yayılmasını durdurmak amaciyla Avrupa'da çevreleme siyasetini uyguladıktan sonra Akdeniz'de ve Ortadoğu'da askeri bir ittifak kurma yoluna gitmiştir. Bu çerçevede Eisenhower Doktrini uygulanmaya çalışılmıştır. Aynı dönemde caydırıcılık stratejisi ile Sovyetler Birliği durdurulmaya çalışılmıştır. Atom bombası sonrası hidrojen bombası ve kıtalar arası füzeler karşılıklı olarak $A B D$ ve Sovyetler Birliği tarafından üretilmiştir. Ortaya çıkan denge, yeni bir savaşın başlamasına engel olmuştur (Dabanlı, 2007, s.66-67). Çevreleme politikasının yanında caydırma politikasının devreye sokulmasının sebebi çevreleme politikasının son derece maliyetli olmasıdır. Yeni bakış stratejisi adıyla da anılan Eisonhower Doktrini, Asya'da ve Ortadoğu'da Sovyetler Birliği'ni çevrelemenin yanı sıra, Sovyetler Birliğinin etkili olduğu Doğu Avrupa Ülkelerinin baskı altına alınmasını, Sovyetler Birliği'nin olası askeri müdahalelerine karşılık misilleme yapma stratejilerinin geliştirilmesini ve CIA'nin daha etkili kullanılmasının sağlanmasını içermektedir. Böylelikle silahlanma yarışı başlamış ve nükleer silah kullanmanın yerine göre mümkün olabileceği bir strateji benimsenmesi sağlanmıştır. Bu teknolojiden müttefik ülkelerinde yararlanmasına ABD tarafından destek verilmiştir. Ayrıca Uluslararası Atom Enerji Ajansı, Birleşmiş Milletlere bağlı olarak kurulmuştur (Şişman, 2015, s.44-45). 
Çevreleme politikası kapsamında ise Türkiye'nin de dahil olduğu "Kuzey Kuşağ 1 Savunma Projesi" oluşturulmuştur. Böylelikle gerek ikili anlaşmalarla gerekse bölgesel örgütler eliyle savunma politikaları hayata geçirilmiştir (Yeşilbursa, 2002, s.107).

Misır ve Suriye gibi ülkelerin bu paktlara girmemesi ve Sovyetler Birliği'ne yaklaşması, Süveyş Kanalı'nın millileştirilmesi ve İsrail'in Mısır'a saldırması gibi gelişmeler Eisenhower Doktrininin oluşmasını tetiklemiştir (The Suez Crisis, 1956, 2018). Başkan Eisenhower 1957 yılında Ortadoğu'da bulunan petrol yataklarını tespit edilmesi ve üç semavi din açısından bölgenin kutsal kabul edildiğinin hesaba katılması temellerine dayanarak Kongre'ye bir belge göndermiş ve Sovyetler Birliği'nin de Ortadoğu'da yayılmacı bir anlayış ile hareket ettiğini ortaya koymuştur. Dolayısıyla Kongre, ABD başkanını çeşitli yetkiler ile donatarak bölge ülkelerine destek verilmesi ve yardım yapılması ile olası bir Sovyet yanlısı askeri güç kullanımı sonrası müdahale kararı alınması yetkisi ile donatmıştır. Bu yetkiler sonrası ABD, Sovyetler Birliği'nin yayılmacı politikalarına karşı güçlü durarak dengeli bir caydırıcılık politikası izlemiş ve sorunların çatışmaya dönüşmeden halledilmesi yoluna gitmiştir. 1959 yılında Küba füze krizi sonrası Türkiye'den Jüpiter füzelerinin sökülmesi kararı, bu duruma çarpıcı bir örnektir (Erhan, 2003, s.2; Arı, 2004, s.224; Dabanl1, 2007, s.66-67).

ABD'nin uyguladığı caydırıcılık stratejisi aslında zamanın şartlarının bir ürünüdür. Sovyetler Birliği ile Avrupa ülkeleri arasındaki güç dengesizliği, ABD ile dengelenmekteydi. Kılıç ve Kalkan Stratejisi olarak da adlandırılan strateji, yalnızca Ortadoğu'yu kapsamıyordu. Avrupa ülkelerine de çeşitli ABD kuvvetlerinin yerleşmesi yine bu stratejinin bir ayağıydı. Böylelikle, Avrupa devletleri birer kalkan haline gelirken, stratejinin kılıç ayağı ABD'nin çeşitli bölgelerde konuşlanmış unsurları olmuştu. 1953 yılında NATO gelişmelere paralel olarak yeni NATO stratejisi kabul edilmişti. Kitlesel Karşılık Stratejisi olarak adlandırılan bu strateji, konvansiyonel kuvvetler ve nükleer güç vasitasıyla Sovyetler Birliğine karşı bir denge unsuru oluşturmak mantığı üzerine kuruluydu (Sander, 1979, s.92; Ersun, 1984, s.25; Jafarov, 2007, s.37). Bunda şüphesiz ABD'nin Stratejik Hava Komutanlığı'nın da etkisi büyüktü. Çünkü ABD gerektiğinde Sovyetler Birliği'nin ve Çin Halk Cumhuriyeti'nin önemli bölgelerine saldırı yapma kapasitesine sahip bulunmaktaydı. Bu durum 
aynı zamanda NATO'ya ait büyük bir kara ordusunun da varlığını gereksiz kılıyordu (Sander, 1991, s.266). Sovyetler Birliğine karşı caydırıcı olarak tutulan nükleer gücün ağırlıklı olarak ABD'nin elinde bulunması ise Avrupa'nın ABD'nin eline bakar duruma gelmesine sebep olmuştu. Avrupa devletleri ise karar alma mekanizmalarında daha fazla yer almak istiyordu. Bu durum ABD'nin hareket kabiliyetini kisitliyordu. Zamanla Sovyetler Birliği'nin kendi silah kapasitesini artırarak ABD'yi vurabilecek güce ve imkana ulaşması ile uzaya askeri bir uydu fırlatması, ABD'nin de artık vurulabilir yakınlıkta olmasını hesaba katması gerektiği gerçeğini doğurmuştur (Turan, 1971, s.20; Gürkaynak, 2008, s.563; Sander, 1991, s.268).

Sovyetlerin Güney Vietnam'ı ve Çekoslavakya'yı işgal ettiği 1960'lı yıllar askeri üstünlüğün tek başına yeterli bir koruma sağlamadığını ABD açısından gözler önüne sermiştir (Çakmak, 2003, s.127-128; Kissinger, 2000, s.664). Başkan Kennedy, Eisenhower'ın Sert Mukavemet Doktrinini eleştirerek nükleer saldırı yerine konvansiyonel savaş ile karşı konulması gerektiğini savunduğu Esnek Karşıllk Doktrinini geliştirmiştir. Bu çerçevede Uluslararası Kalkınma Ajansı kurulmuş ve müttefiklere yapılan yardımların artırılması yoluna gidilmiştir (Neumann, 2018, s.1). Bu dönemde ABD Küba'nın işgaline kalkışmış ancak başarısız olmuştur. Gelişmeler Berlin Duvarı'nın inşaatına kadar gitmiştir (Kennedy's Foreign Policy, 2018).

Başkan Kennedy'nin suikast sonucu öldürülmesi sonrası yardımcısı Johnson göreve gelmiştir. Kennedy ile aynı yöntemleri izleyeceğini açıklayan Başkan Johnson, kendi döneminde Asya Pasifik bölgesindeki sorunlar ile uğraşmıştır. Barış politikası Vietnam Savaşı'nın başlangıcına kadar devam etmiştir. Başkan Johnson aldığ1 yetki ile sürekli olarak bölgedeki asker sayısını artırma yoluna gitmiştir. Benzer politikalar Latin Amerika için de uygulanmıştır. ABD Latin Amerika'ya binlerce asker göndermiştir (Kurat, 1964, s.22-23; Shulzinger, 1990, s.273-278).

Başkan Nikson dönemi, Vietnam Savaşı nedeniyle askeri harcamaların artmış olduğu bir döneme denk gelmiştir. Bu problemlerden sıyrılmak için Nikson ABD'nin gerektiğinde müttefiklerine nükleer bir koruma sağlayacağını ve nükleer olmayan çatışmalar için de imzalamış olduğu bütün uluslararası anlaşmalardaki yükümlülüklerini yerine getireceğini açıklamıştır. Bu çerçevede gerekli her türlü lojistik desteğin ve ekonomik 
yardımların verileceğini söylemiştir (Meiertöns, 2010, s.142-143). Nikson bu anlayış ile ABD askerlerini Vietnam'dan çekmeye başlamıştır. Bunun yanında Vietnam'da kullanılan askeri malzemeler de Güney Vietnamlılara devredilmiştir. Bu politikalar ABD'nin desteklediği Güney Vietnamlıların teslim olmasıyla sonuçlanmıştır (Fry, Goldstein ve Langhorne, 2002, s.412-413).

$A B D$ ve Sovyetler Birliği arasında devam eden Soğuk Savaş, bu dönemde çözülmeye başlamıştır. Her iki devlet için nükleer silahlanmanın maliyetinin çok yüksek olması ve büyüyen askeri bütçenin maliyetinin artık başka sorunlara sebep olması, silah müzakerelerinin başlamasına sebep olmuştur. Çin ve Sovyetler Birliği arasındaki soğukluğun da etkisiyle $A B D$ ve Sovyetler Birliği daha dengeli bir ilişki kurmuşlardır. ABD'nin Vietnam'da zorlanması da yine ılımlı ilişkilerin başlamasının nedenlerindendir. Başkan Nikson, 1972 yılında Sovyetler Birliği'ni ziyaret etmiş ve Stratejik Silahların Sınırlandırılması Anlaşması'nı imzalamıştır (Şişman, 2015, s.51-52).

Carter dönemi Sovyetler Birliği'nin Afganistan'ı işgal ettiği ve İran'da İslam Devrimi'nin olduğu dönemdir (Dumbell, 1995, s.202-203). Sovyetler Birliği'ni durdurmak amacıyla bir dizi karar çıkarılmış ve belirli ürünlerin Sovyetler Birliği'ne ihracatı durdurulmuştur. Ayrıca Afganistan'da Sovyetler Birliği ile savaşan gruplara da gizli bir şekilde silah yardımı yapılmıştır (Caldwell, 2011, s.38-39). Bu dönemde yüzlerce askeri üs açılmıştır. Ayrıca 200.000 hazır kuvvetten müteşekkil Acil Müdahale Gücü oluşturulmuştur (Orme, 1983, s.61). Bunlara ek olarak daha önce imzalanan silahsızlanma anlaşmasının ikincisinin imzalanmasını da askıya almiştır (Kavuncu, 2013, s.126).

1983 yılında göreve gelen Başkan Reagen ile Sovyetler Birliği lideri Gorbaçov arasında orta menzilli füzelerin kaldırılması amacıyla Orta Menzilli Nükleer Füzeler Antlaşması imzalanmıştır. Aynı dönemde ABD, Grenada'yı işgal etmiştir. Bunun dışında ABD kontrgerilla politikası ile muhtelif yerlerdeki gerilla gruplarına destek vermiştir (U.S.-Soviet Relations, 2018; Central America, 1981-1993, 2018). İsrail'in güvenliğinin sağlanması amacıyla ise Acil Müdahale Ortak Görev Gücü kullanılmıştır (Arı, 2004, s.245). Görüldüğü üzere ABD, bu dönemde öncelikle Sovyetler Birliğinin yayılmacı politikalarını önlemek üzere öncelikle çerçeveleyici bir politika izleyerek birliğin çevresindeki ülkeleri ve politik unsurları 
kullanmıştır. İkincil bir politika olarak ise nükleer silah unsurunu kullanarak birliğe karşı caydırıcı bir politika izlemiştir.

\section{0'11 Y1llar}

Sovyetler Birliği ile Stratejik Silahların Azaltılması Anlaşmasının imzalandığı 1990'lı yıllar, aynı zamanda Soğuk Savaşın da sona erdiği yıllardır (kavuncu, 2013, s.137). Berlin Duvarı'nın yıkılması ile başlayan süreç art arda Doğu Avrupa ülkelerinde iktidarların değişmesi ile devam etmiştir. Almanya NATO'ya üye olmuş, Ukrayna ve Beyaz Rusya da bağımsızlığını ilan etmiştir. İşte bu dönemde ABD Başkanı olan George H. W. Bush Yeltsin'i desteklemiş ve reformların yanında bir tutum izlemiştir. Sonuç olarak Rusya'da Gorbaçov görevi Yeltsin'e bırakmıştır (Kavuncu, 2013, s.137; Fall of Communism in Eastern Europe, 1989; The Collapse of The Soviet Union).

George H. W. Bush döneminde güvenlik açısından belki de en önemli olay Körfez Savaşıdır. Körfez savaşı ile ABD Ortadoğu'ya askeri anlamda yerleşmeye başlamıştır. Bu olay ABD'nin Ortadoğu'yu şekillendirme imkanı kazanmasına kapı açacaktır. Ancak Sovyetler Birliği'nin çöküşünden sonra $\mathrm{ABD}$ için farklı bir düşman ufukta görünmeye başlamıştır. Ortaya çıkan Radikal İslam tehdidi ABD ile beraber NATO'nun konseptinin de dönüşmesine sebep olacaktır (Dabanlı, 2007, s.69-70).

Ortadoğu'ya yerleşmeye başlayan ABD, İran ve Irak gibi ülkelere karşı "Çifte Kuşatma Stratejisi" adını verdiği stratejiyi uygulamaya başlamıştır. $\mathrm{Bu}$ strateji düşman görülen devletleri uluslararası arenada yalnızlaştırmanın yanı sıra baskı yapılması suretiyle dönüştürme çabasını ifade etmektedir. ABD bu şekilde Irak'1 zayıflatarak rejimi darbe ile yıkma yoluna gitmek istemiştir (Dabanlı, 2007, s.73).

Başkan Clinton döneminde ise Birleşmiş Milletler eliyle Çifte Kuşatma Stratejisi uygulanmaya devam edilmiştir. İran ve Irak yönetimlerine ambargolar konularak bu ülkelerde iç dinamikler eliyle rejim değişikliği yapılmaya çalışılmıştır (Kayar, 2003, s.197). Daha sonra Avrupa ülkelerinin baskısıyla bu strateji yerine "Eleştirel Diyalog Stratejisi" uygulanmaya başlanmıştır (Uzgel, 2002, s.246). Düşman görülen ve "Serseri Devletler" olarak tanımlanan ülkelere ise "Karşı Savunma İnisiyatifi" adıyla uygulanan politika, bu ülkelerin nükleer birer güç haline gelmesini 
engellemek amaciyla hayata geçirilmiştir. Askeri önlemler yerine ekonomik yaptırımlar ile düşman gördüğ̈̈ devletlere baskı uygulayan $\mathrm{ABD}$, bu stratejisini ikili anlaşmalar ve uluslararası örgütler eliyle uygulama yoluna gitmiştir (Gürses, 2003, s.50). Bunun yanındaa çifte kuşatma stratejisi ile bu devletri fiili anlamda da control altında tutumuştur. ABD'nin içinde bulunulan dönemde devam eden Büyük Ortadoğu projesinin kalın çizgileri de bu dönemde çizilmeye başlanmıştır.

\section{Eylül ve Sonrası Dönemi}

Soğuk Savaş sonrası ABD, terörizmi öncelikli tehdit olarak görmeye başladı. 11 Eylül saldırıları ile bu tehdit algısının doğru olduğu ortaya çıkmış oldu (Canbolat, 2003, s.158-159). Gelişen olaylar ise ABD'nin istediği pek çok şeyi yapmak konusunda meşruiyet sorununu aşmasına yardımcı olmuştur (Erkmen, 2001, s.13). ABD Diş İlişkiler Konseyi'nin 2003 yılında hazırladığı rapora göre ABD'nin kolluk kuvvetlerinin, bu tarz bir saldırıya karşı koymak konusunda yeterince donanım ve eğitimden yoksun olduğunu gözler önüne sermiştir (Ataöv, 2003, s.94).

11 Eylül saldırıları ABD'nin müttefiklerine olan ihtiyacını ortaya çıarması açısından da önemlidir. Bu ihtiyaç kuşkusuz dış politikayı da etkileyecektir. Örnek olarak Çin'in insan hakları ihlallerinin, Çin'e duyulan ihtiyaçtan dolayı daha az dile getirilmesi, bu durum için bir dışa vurumdur. Olayın bir başka yönü ise ABD'nin artık tek taraflı davranamayacağını göstermesidir. Pek çok uluslararası anlaşmanın imzalanması, 11 Eylül saldırıları öncesi dönemde ABD tarafından yapılmamıştır. Bush yönetimi 2002 yılında yeni Ulusal Güvenlik Stratejisini açılamıştır. Buna göre ABD mutlak kontrole dayanan bir güvenlik anlayışına geçtiğini ilan etmiştir. Artık ortaklıklar ile çevreleme ve caydırıcılık gibi politikalar veya önleme stratejisi yerine ön-alma stratejisi uygulanacaktır. Tehditler yerine olasılıklara dayanan bir savunma anlayışına geçen $\mathrm{ABD}$, düşman gördüğ̈̈ unsurlarda bir saldırı niyeti olduğu iddiasıyla savunma yapabilmek için çeşitli tedbirlere başvurabilecektir (Amanov, 2007, s.38-41).

Saldırıların sorumlusu olarak görülen El Kaide örgütünün peşine düşmek amacıyla ABD Afganistan'a saldırmıştır. Ayrıca teröre destek veren ülkelere de saldıracağını açıkça ilan eden $A B D$, pek çok ülkeye de askeri üs kurmak istediğini belli etmiştir. Asya Pasifik'te tatbikatlar yapan 
ABD pek çok ülkeyle ilişkilerini de gözden geçirmiştir. Bu durum ABD'ye Çin'i ve Rusya'yı çevreleme imkanı da vermiştir. Terörizmle mücadele stratejisi adı altında ABD'nin kendi ifadesiyle kötülüğe karşı yapılan bu savaşta pek çok ülkeyi ilgilendirecek şekilde farklı metotlara başvuracağı, George Bush tarafından açıkça dile getirilmiştir. Başkan Bush ilişkilerinin sorunlu olduğu ülkelerle anlaşmazlıkları ikinci plana atarak, bütün ülkeleri kendilerine destek olmaya çağırmıştır. Ulusal Güvenlik Stratejisi açıklamasında ise tüm dünya insanlarını ilgilendiren bir savaşa girildiğini anlatmış ve büyük güçlerin de kendisi ile beraber hareket edeceğini ilan etmiştir. Ülkelere yapılacak olan müdahaleler, Bush yönetimine göre demokrasi adına yapılacaktır. Her ülkeye müdahale edilebileceğinin sinyalinin verildiği konuşmada kitle imha silahlarının $A B D$ ve müttefikleri için birer tehdit unsuru sayıldığı açıklanmıştır. Böylelikle İran ve Irak hedef gösterilmiştir. Tehlikeli olarak ifade edilebilecek unsurlara karşı ise sivil toplum kuruluşlarının destekleneceği belirtilmiştir. Müdahalenin coğrafi sınırları ise bütün dünyayı kapsamaktadır. Önleyici saldırı kavramı ile de ABD kendisine yönelik bir tehdit algısının olması durumunda bütün uluslararası kurallara rağmen müdahale etmekten çekinmeyeceğini ilan etmiştir. Orta Asya ve Hazar enerji kaynaklarının da bahsedildiği konuşmada Bush yönetimi buraları kontrol altına alma isteğinin de sinyallerini vermiştir. Uluslararası arena için ise 11 Eylül saldırılarının ve yeni güvenlik paradigmasının ABD işgalleri için bir bahane olarak kullanılacağı korkusu ortaya çıkmıştır. Önleyici müdahale stratejisi bu anlamda tartışmalı hale gelmiştir. Terörizm yapısı gereği öngörülemeyen saldırılar ile düşmanı yıpratma stratejisini içinde barındırmaktadır. Nerede ne zaman ortaya çıkacağı belli olmayan bir tehdit için kullanılabilecek en etkili stratejinin önleyici müdahale stratejisi olduğu savunulsa da Irak işgali sonrası Irak'ta olanlar endişeleri haklı çıkarmıştır. Bir diğer konu ise herhangi bir unsurun ABD'yi tehdit edebilecek güce ulaşmasına izin verilmeyeceğinin ortaya konmasıdır. Böylelikle Birleşmiş Milletler Güvenlik Konseyi devre dışı bırakılmıştır. Ortaya çıkabilecek olan hukuksuzluklar ABD'ye çok büyük imkanlar sağlamaktadır. Örneğin Irak işgali konusunda Irak'ın 11 Eylül saldırıları ile bağlantısının kurulamamış olması uzun süre dünya kamuoyunda tartışılmıştır. Yani aslında mesele sadece hukuki altyapının eksik olması değildir. Aynı zamanda ABD'nin yaptıkları meşruiyet çerçevesinden de 
sorgulanmaktadır. NATO Anlaşmasının 5. Maddesi kapsamında ABD'nin Birleşmiş Milletlerin onayı olmadan Afganistan'a saldırması bu sorgulamaları haklı çıkarır niteliktedir (Dabanlı, 2017, s.73-96; Öztürk, 2002, s.16-21, Çimen, 2007, s.53-54).

11 Eylül saldırılarından sonra çokça konuşulan Büyük Ortadoğu Projesi, 2002 yılında Colin Powell tarafından dile getirilmiştir. Irak'a götürülen demokrasinin diğer Ortadoğu ülkelerine de götürüleceği söylemleri ile desteklenen proje aynı zamanda ABD-Ortadoğu Serbest Ticaret Bölgesinin kurulmasını da içeriyordu. Başkan Bush'un Güvenlik Danışmanı Condoleezza Rice, 2003 yılında yazdığı bir yazıda Fas'tan Basra Körfezi'ne 22 devletin sınırlarının değiştirilerek buradaki ülkelerin yeniden yapılandırılacağını açıklamıştır. Daha sonra ABD'nin G-8 ülkeleri ile yaptığ 1 toplantılar neticesinde proje genişletilerek Geniş Ortadoğu ve Kuzey Afrika projesine dönüşmüştür. Bu toplantılarda kullanılan taslak belgenin basına sızmasıyla proje hakkında daha detaylı bilgiler açığa çıkmıştır. $\mathrm{Bu}$ belgeye göre G-8 ülkeleri için Arap ülkelerindeki özgürlüklerde ve bilgide eksiklikler olması ile kadın haklarının durumu tehdit olarak geçmektedir. Çünkü bu hususlar terörizmi, organize suçları ve yasa dişı göç ile radikalleşmeyi beslemektedir (Urul, 2008, s.172-174). Belgeye göre, bu gibi temellerden beslenecek ve fiiliyata geçecek olan terör hareketleri ve oluşumları önlenmelidir.

\section{Yılı ve Sonrası Dönem}

2006 yılında yayınlanan ABD'nin Ulusal Güvenlik Strateji Belgesi, 2002'de yayınlanan belgenin biraz daha genişletilmişidir. Her iki belgeye de kitle imha silahlarının yayılması, hastalıklar ve terörizm ile kaçakçılık gibi unsurlar tehdit olarak dahil edilmiştir. Gerek 2002 yılında yayınlanan belgede gerekse 2006 yılında yayınlanan belgede ittifaklar kurmak konusunda vurgu vardır. Ancak 2006 yılında yayınlanan belge tek taraflılık yerine çok taraflılığa daha çok gönderme yapmaktadır. Demokratik toplumlar oluşturulması suretiyle dünyayı geliştirmek ve toplumları açık hale getirmek, yine her iki belgede de bulunan başlıklardır. Ayrıca ABD'nin ulusal güvenlik organizasyonlarını dönüştürme isteği de yine göze çarpan başlıklardandır. Ek olarak uyuşturucu kaçakçlığına ve enerji güvenliğine bu belgelerde özel bir yer verilmiştir. Terörizm ve kitle imha 
silahlarına karşı ise önleyici vuruş yapılarak önleme faaliyetleri yapılacaktır. 2006'da yayınlanan belgeye, 2002'de yayınlanan belgeye ek olarak "Küreselleşmenin Fırsatlarını Yakalamak ve Meydan Okumalara Karşı Koymak" başlığı eklenmiştir (The White House, 2006, s.7-32; The White House, 2002, s.1-19).

$\mathrm{Bu}$ politikalar çerçevesinde İç Güvenlik Bakanlığı'nın kurulduğu $\mathrm{ABD}$ 'de, ülke içerisinde terör saldırılarının olmasını engellemek amacıyla 22 kurum bu bakanlığın yönetimine verilmiştir. Aynı zamanda bu bakanlık, diğer kurumlara da terörizmle mücadele konusunda stratejik anlamda destek sağlayacaktır. 2001 yılında kabul edilen Patriot yasası ağırlıklı olarak sınır kontrolleri ile mali suçları kapsamaktadır. Bu yasada terörizmle mücadele gerekçesiyle pek çok hak ihlali yapıldığı belirtilmektedir. Ayrıca Patriot yasası ABD'nin iletişim kanallarını da denetlemesine imkan vermektedir. Son olarak 2004 yılında yapılan istihbarat reformu ile $\mathrm{ABD}^{\prime}$ de bulunan istihbarat kurumlarının bilgi paylaşımını artırmak ve koordinasyonunu gerçekleştirmek için tek merkezde toplanması sağlanmıştır (Bilensoy, 2018, s.62).

Barack Obama'nın başkan seçilmesi öncesinde ABD'de yumuşak güç kavramı dillendirilmeye başlanmıştır (Gezici, 2009, s.11). Yumuşak güç kullanımından kasıt diplomatik yöntemlere ağırlık verilmesidir. Böylelikle ABD'nin bozulan imajı da düzelecektir (Bilensoy, 2018, s.64). Demokrasi ve insan hakları temelinde gerektiğinde askeri müdahaleler yapılabileceği ile uluslararası örgütlerin güçlendirilmesi mantığı ile hareket edilmesi gerektiği söylemleri, Obama dönemini özetlemektedir. Hükümetler arası işbirliğinin geliştirilerek terörizme karşı verilen savaşın sert fiziksel yöntemlerinin yanı sıra diplomatik düzeyde unsurların da kullanılması gerektiği mantığ1 bu dönemde güçlenmiştir (Ermağan, 2012, s.28). Ancak güvenliğin sağlanması için temel dayanak yine askeri güçtür. Çok taraflılığa vurgunun yapıldığı Ulusal Güvenlik Stratejisi Belgesinde yapılacak ittifaklara da dikkat çekilmiştir. Belgede Irak Savaşı'nın bittiği belirtilmiş, ancak hedefi ve süresi belli olmayan bir savaş yerine Irak'ta ve Afganistan'da olduğu gibi belirsiz olmayan mücadeleler ile güvenliğin sağlanabileceği anlayışı oturtulmaya çalışılmıştır. (The White House, 2010). Bu çerçevede terörizm ile mücadele amacıyla yapılan Afganistan ve Irak işgallerinin yanı sıra NATO'nun ve Birleşmiş Milletlerin daha aktif hale getirilerek çok taraflı yapılar eliyle güvenliğin sağlanması anlayışına 
geçilmiştir. Ayrıca Avrupa ile işbirliği çerçevesinde hava ulaşımının güvenliğinin sağlanmasına da çalışılmıştır (Özeren, Cinoğlu ve Sever, 2010, s.29).

Trump dönemi ABD'nin yalnızlaştığına dair eleştirilerin olduğu bir dönemdir. Göreve başladıktan sonra Transatlantik Ticaret ve Yatırım Ortaklığı Anlaşmasından ve İran ile yapılmış olan nükleer konulu antlaşmadan ABD'nin tek taraflı olarak çekildiği bu dönem, uluslararası arenada ABD'nin imajını olumsuz yönde etkilemiştir. Özellikle ABD'nin ekonomik gücünü dost ve düşman gördüğü bütün ülkelere karşı silah olarak kullanan Başkan Trump, İran'ı da en büyük düşman şeklinde ilan etmekten çekinmemiştir. Birleşmiş Milletlere ayrılan bütçeden bile kesinti yapan ABD yönetimi, NATO konusunda ise kendisi diğer ülkelerden daha fazla para verdiği için kendi çıkarını ittifak kurduğu ülkelerden daha önde tuttuğunu açıkça haykırmaya başladı. İsrail'e verilen önemden dolayı yalnızlaşmaya başlayan ABD'nin Başkan Yardımcısı Mike Pence, yaptığı ziyaretlerde hiçbir Filistinli lider ile temas kuramadan geri dönmek durumunda kaldı. Bu durum ABD'nin arabulucu olma iddiasını zedeledi. Bu gelişmeler ABD'nin güvenilirliğini düşürürken, tek taraflı hareket etme konusunda da ciddi eleştirilere maruz kalmasına sebep olmaktadır. Trump yönetimi Çin ile de restleşerek Çin'den gelen ürünlere ek vergiler koyma yoluna gitmiştir (Üstün, 2018). Şüphesiz bunların altında Başkan Trump'ın Çin'i büyük bir tehdit olarak görmesinin etkisi büyüktür. Ayrıca ABD Başkanı Trump için tek tehdit Çin de değildir. Nükleer silah tehdidine de önem veren Trump, İran ile yapılmış olan anlaşmayı bu sebepten iptal etmiştir. ABD'nin güç kaybettiğini, buna karşın Çin'in ve Rusya'nın (Sadioğlu ve Erdinçler, 2018, s.75) güç kazandığını her fırsatta dile getiren Trump, Daeş'i ise Çin'den daha alt seviyede bir tehdit olarak gördüğünü ifade etmektedir (Yalçın ve İlhan, 2017, s.9-10).

Trump dönemi Ulusal Güvenlik Stratejisi Belgesinde siber güvenliğe vurgu yapılmıştır. Aynı belgede ABD'nin ekonomisinin canlandırılarak diğer devletlerle mütekabiliyet esaslarına göre hareket edileceği de anlatılmıştır. Enerji hakimiyetine verilen önemin belirtildiği belgede ABD Ordusunun yeniden yapılanacağından da bahsedilmiştir. Uzay çalışmalarına da vurgunun yapıldığı belgede ağırlıklı olarak güç ile beraber caydırıcılık üzerinde durulmuştur. Çok uluslu organizasyonlar ise bu belgede ABD'nin kendileriyle yarışacağı yapılar olarak tarif edilmektedir. 
Zayıf ülkelere yardım ederek terörizmin otorite boşluğundan yararlanmasının önüne geçme stratejisinin de anlatıldığı belgede gelişmekte olan ülkelerde reformlar yapılmasına teşvik edici faaliyetlerden bahsedilmiştir (The White House, 2017). ABD'nin 2017 yılında yayınlanan Ulusal Güvenlik Belgesinde ilk defa ekonomik güvenlik, ulusal güvenliğin alt kollarından biri olarak tanımlanmıştır. Ordunun modernize edilerek gereksiz bürokrasinin tasfiye edilmesi ve modernizasyonun giderlerinin bir kısmının müttefiklerden karşılanması anlayışı belgede açıkça dile getirilmiştir. Kuzey Kore'ye karşı alınan önlemlerin de anlatıldığı belgede uzayın da yeni bir rekabet bölgesi olarak görüldüğü anlatılmıştır. Son olarak NATO müttefikleri için 2024 yılına kadar kendi GSYH'lerinin \%2' sini savunma harcamalarına ayırmalarını, bu paranın da 5'te 1'inin askeri yeteneklerin artırılmasına kullanılması gerektiği, ABD'nin NATO'da kendi görevlerinin üzerinde bir efor sarf ettiği ancak diğer NATO ülkelerinin aynı çabayı göstermedikleri meselesi, belgede öne çıkan bir başka konudur. Obama döneminin aksine iklim değişikliği konusuna ise belgede hiç değinilmemiştir. Bunun yerine Rusya, Çin, Kuzey Kore, İran ve terörizm unsurları ABD'nin güvenlik anlamında kendisi için tehdit gördüğü unsurlar olarak belgede yer almıştır. ABD'nin Ulusal Güvenlik Stratejisi Belgesindeki yeni anlayışı, daha çok dahili önlemler ile sağlanan güvenlik odaklıdır (Seren, 2018, s.9-13).

Buraya kadar ele alınan konular doğrultusunda, ABD'nin kuruluşundan bu yana özümsediği güvenlik anlayışını ve ulusal güvenlik politikası kronolojik olarak aşağıdaki tabloda olduğu gibi özetlenebilecektir. Söz konusu anlayışların oluşmasında etkide bulunan düşünceler ve olaylar da politikaların kaynaklarının daha iyi kavranmasına ve anlamlandırılmasına şüphesiz ki büyük katkıda bulunacaktır. 
Tablo 1. ABD'nin Kronolojik-Dönemsel Güvenlik Politikası

\begin{tabular}{|c|c|c|}
\hline Dönem & Hakim Ulusal Güvenlik Anlayışı & $\begin{array}{l}\text { Anlayışa Etkide Bulunan } \\
\text { Olay ve Akımlar }\end{array}$ \\
\hline Kuruluş Dönemi & Kabuğuna çekilmeci/Savunmacı & $\begin{array}{l}\text { Monroe Doktrini } \\
\text { Manifest Destiny (Açık } \\
\text { Kader) }\end{array}$ \\
\hline I. Dünya Savaşı & Yumuşak konuş, büyük sopa taşı & $\begin{array}{l}\text { New Deal } \\
\text { Wilson Prensipleri }\end{array}$ \\
\hline II. Dünya Savaşı & $\begin{array}{l}\text { Dayanışma temelli güvenlik } \\
\text { anlayışı }\end{array}$ & $\begin{array}{l}\text { Marshall Planı } \\
\text { Yalta Konferansı }\end{array}$ \\
\hline Soğuk Savaş Dönemi & Caydırmacı/İttifakçı/Birleşmeci & $\begin{array}{l}\text { Çevreleme Politikası } \\
\text { Eisonhower Doktrini } \\
\text { Caydırma Politikası } \\
\text { Esnek Karşılık Doktrini }\end{array}$ \\
\hline 1990'l1 Yillar & Kuşatmacı & $\begin{array}{l}\text { Radikal İslam Tehdidi } \\
\text { Çift Kuşatma Stratejisi } \\
\text { Eleştirel Diyalog }\end{array}$ \\
\hline 11 Eylül ve Sonrası & $\begin{array}{l}\text { Ön-almaci/Mutlak Kontrol/İnti- } \\
\text { kamc1 }\end{array}$ & $\begin{array}{l}\text { Terör Saldırıları } \\
\text { Büyük Ortadoğu Projesi }\end{array}$ \\
\hline 2006 ve Sonrası & $\begin{array}{l}\text { Yumuşak güç/ } \\
\text { Diplomasi Vurgusu/Çok taraflılık }\end{array}$ & $\begin{array}{l}\text { Nükleer Silahlanma } \\
\text { Kitle İmha Silahları } \\
\text { Siber Güvenlik }\end{array}$ \\
\hline
\end{tabular}

Kaynak: Yazarlar tarafindan oluşturulmuştur.

\section{Sonuç}

ABD kuruluşundan bir süre sonra kendi sınırlarını aşarak önce bulunduğu kıtaya, daha sonra ise dünyanın diğer coğrafyalarına müdahale etmeye ve yayılmaya başlamıştır. Özellikle İkinci Dünya Savaşı süresince ve bu savaşın sonrasında ortaya çıkan güvenlik boşluğunu doldurmak durumunda kalan ABD, Soğuk Savaş döneminde Avrupa'yı Sovyetler Birliği'ne karşı koruma rolünü üstlenmiştir. Soğuk Savaş'ın bitmesinden sonra ABD kendisine yeni düşman olarak Terörizmi görmüştür. Özellikle 11 Eylül saldırılarından sonra kendi ifadesiyle terörizm ile mücadele için dünyanın her bölgesinde pek çok önleme başvuran ABD, Irak'ı ve Afganistan'ı işgal ederek bu ülkelerde kendisi ile müttefik olacak yönetimler tesis etmiştir. Ancak ABD'nin bu stratejisi, savunma harcamalarının çok artmasına sebep olmuştur. Ayrıca terörizm gibi görünmez ve öngörülemez bir tehdit ile mücadele ettiğini ilan eden $\mathrm{ABD}$, bu çerçevede kendisine yapılmış bir saldırı olmasa bile gerekli gördügünde müdahale imkanlarının tamamını kullanarak kendi tehdit algıSı 
dahilinde hemen her türlü önleme başvurabileceğini de beyan etmiştir. Ancak süreç $\mathrm{ABD}$ için öyle bir noktaya gelmiştir ki artık ne bir uluslararası oluşum, ne de uluslararası bir kural, yapılacak olan faaliyetler için engelleyici olmaktan çıkmıştır. Her geçen gün daha da saldırganlaşan ABD, Obama döneminde toparlamaya çalıştı̆̆ı uluslararası imajını, Trump döneminde tekrar kaybetme tehlikesiyle karşı karşıya kalmıştır. İmzalanan uluslararası anlaşmalardan tek taraflı olarak çekilebilen hatta müttefiklerini bile tehdit eden ABD, uluslararası arenada güvenilirliğini kaybetmektedir. Aslında Bush döneminde askeri anlamda önleyici savaş stratejisinin ekonomik anlamda bir devamı olan Trump dönemi söylemleri, her ne kadar ABD'nin artık küresel ölçekte tek başına at koşturamadığının itirafını kendi içerisinde barındırsa da, çelişkili bir durum olarak kendi başına hareket etmeye meyilli ve her unsuru tehdit ederek sindirmeyi göze alan bir anlayış ile öne çımaktadır.

İsrail'in en önemli dost olarak görüldüğü $\mathrm{ABD}$ güvenlik konseptinde, ABD birliklerinin peyderpey Asya'ya kaydırılması da şaşırtıcı değildir. Çünkü ABD'nin güncel strateji belgesinde en büyük düşman olarak Çin Halk Cumhuriyeti anılmaktadır. Bu durum tehdit algisının terörizmden farklı bir yöne kaydığının da göstergesidir. Elbette $\mathrm{ABD}$ 'nin girdiği ülkelerden tam anlamıyla çıkması, daha büyük açıklara neden olacaktır. Ortadoğu ABD için kendi kaderine bırakılamayacak kadar önemlidir. Ancak Asya'da yükselen büyük tehdit öncelikli olarak durdurulmalıdır. Asya'da ki tehdidin durdurulması için gerekenler ise Ortadoğu'da ki hakimiyet ile mümkündür. ABD'nin bu noktada sorumlulukları müttefiklerine yıkarak kendi aktif gücünü daha sembolik bir şekilde kullanmayı deneyeceği ihtimal dahilindedir.

Müttefiklerine yaklaşma mantığı, her bir devletin yaptığı ödeme kadar söz ve hak sahibi olacağı anlayışı üzerine kurulu olan Trump dönemi paradigması, benzer bir yaklaşımı müttefik görmediği ülkelere de çevirme emareleri göstermektedir. Kuzey Kore meselesinin Çin'e ait bir mesele olduğu ve ülkenin sorunu çözmekle mükellef bulunduğu söylemleri, aynı anlayışın dışa vurumdur. Trump'ın güvenlik anlayışında önleyici bir savaş metodu olmasa da aslında ekonomik anlamda önleyici tedbirler ile hareket edildiği net bir şekilde görülmektedir. İran ile imzalanan nükleer anlaşmadan, ilerleyen dönemlerde İran'ın nükleer gücü geliştirebileceğini söyleyerek çekilmesi ve ambargo uygulaması, ABD'nin bu anlayışının askeri 
olarak olmasa da gerek ekonomik, gerekse diplomatik olarak devam ettirdiğinin göstergesidir.

ABD'nin son Stratejik Güvenlik Belgesinde enerjiye ayrı bir önem atfedilmiştir. Enerji güvenliği son derece geniş bir konudur. Enerji güvenliğinin sağlanması için enerji yollarına hâkim olunmalı hatta üretiminden dağıtımına ve tüketimine kadar her basamakta sürece ve coğrafyaya hâkim olunmalıdır. Bunun farkında olan ABD, enerjinin Avrupa'ya güvenle taşınabilmesi için Asya Pasifikte çeşitli tatbikatlar yapmıştır. Kendisinin karşısında en büyük tehdit olarak gördüğü Çin' de ticaret yollarına hâkim olabilmek için çeşitli projeler oluşturmakta, pek çok ülkeye teşvikler ve destekler vermektedir. Sürecin bu şekilde gitmesi halinde enerji yolları ile ticaret yollarının Çin'in eline geçmesi şaşırtıc bir sonuç değildir.

Başkan Bush döneminden bu yana $\mathrm{ABD}$, uluslararası örgütlere meydan okumaktadır. Kendi çıkarları konusunda son derece saldırgan bir politika izleyen $\mathrm{ABD}$, yeri geldiğinde uluslararası hukukun unsurlarını devre dışı bırakabilmektedir. Bu durum aslında İkinci Dünya Savaşı sonrası dönemde kurulmuş olan uluslararası organizasyonların artık günümüz ihtiyaçlarını karşılamadığının da kanıtıdır. Ortaya çıkan boşluğun ise ne ile doldurulacağı bir muammadır. Henüz dünya güçleri arasında şimdiki duruma uygun bir dengenin oturmamış olması, bahsedilen boşluğun en azından bir süre daha doldurulamayacağını göstermektedir.

Son olarak ordunun modernizasyonu ile siber tehditler ve uzay atılımları gibi yönleri ile ele alınması gereken Trump'ın güvenlik anlayışının aslında ABD'nin savunma harcamalarının maliyetini kısmak istese de bahsedilen uygulamaların tam tersi bir sonuca sebep olabileceği düşünülmelidir. ABD'nin kendi güvenliğini uzaydan sağlamaya kalkışması yeni bir fikir değildir. Söz konusu fikir daha önce denenmiş ancak yüksek maliyetleri sebebiyle bu metottan vaz geçilmiştir. Büyük güçleri büyük olmaya götüren şey, insanlık tarihinde yaşanan tecrübelerden ders çıkarmaktır. 


\section{EXTENDED ABSTRACT}

\section{A Chronological Perspective on US Security Approach within the Framework of National Security Policy \\ * \\ Onur Gündüz - Volkan Göçoğlu \\ Police Academy, Kocatepe University}

The United States was founded with the immigration of many European countries, the unification of the colonies of England, and later the declaration of independence. Although there are many reasons for migration, there are mainly reasons for establishing a new life and escaping the oppression of Christian churches. The fact that the migrant groups have a Christian and Liberal perspective predominantly influenced the institutional structure of the state and shaped the perception of security and thus the security policies.

Unlike European states, the United States had enormous resources and a large amount of vacant land due to its geography. This allowed the US to develop faster. The developing state first began to spread to its immediate surroundings and then to the world in terms of both military and economic terms and culturally. This is undoubtedly influenced by the state of the world, the great wars and capital flows. However, especially in the post-Cold War era, the United States, acting as the sole ruler and owner of the world, started to pursue a more aggressive policy with the emergence of different forces and the changing perception of threat.

In this study the evolution of USA's national security strategies is handled since its establishment up to now. In the section of establishment period it's studied that USA's perception of security which is parellel to its philosophy. After the establishment of the US, it has crossed its borders and started to intervene and spread to the continent and then to other geographies of the world. In the section of the period after world war I and II, it's elucidated how world wars propel USA to be an intervenor to Europe and other countries. After the establishment of the US, it has crossed 
its borders and started to intervene and spread to the continent and then to other geographies of the world. After the end of the Cold War, the US saw terrorism as its new enemy. Especially after the September 11 attacks, the United States, which applied many measures in every region of the world to fight terrorism in its own words, occupied Iraq and Afghanistan and established administrations that would be allied with them in these countries. However, this strategy of the USA has caused the defense expenditures to increase considerably. In addition, the United States declared that it was fighting an invisible and unpredictable threat like terrorism and declared that even if there was not an attack on it, it could use all the means of intervention when it deemed necessary and resort to almost all kinds of measures within its own perception of threat. the process has reached such a point for the US that neither an international entity nor an international rule has ceased to be a hindrance to the activities to be carried out. The US, which is getting more and more aggressive with each passing day, is in danger of losing its international image that it tried to recover during Obama period. The United States, which can unilaterally withdraw from the signed international agreements and even threatens its allies, loses its credibility in the international arena. In fact, the Trump era rhetoric, which is an economic continuation of the military preventive war strategy during the Bush era, tends to act on its own as a contradictory situation where it is threatening to act on its own.

It's put forward that the term of President Trump is another milestone in USA's politics just as September 11 attacks. Acting with the claim that it is the only ruler of the world after the Cold War, the US has continued to advocate its values of organization as discourse, but it has evolved out of its establishment values against the threat of terrorism which is unclear. The Trump period paradigm, which is based on the logic of approaching its allies and the understanding that states will have as much promise and rights as payment they pay, shows a similar approach to unfriendly countries. Although beginning of this logical evolution coincides with the Bush term, it peaks by Trump. What is more interesting that President Trump has a line that holds strength and doesn't care much about diplomacy. In this study, it's discussed what USA's tendency for national security is and where it is going with its self contradictions. USA put security in front of 
freedom however it often expresses that it does so for freedom. The shifting paradigm causes many dissenting voices emerge in and out of the United States, and increase dissatisfaction with the United States.

Lastly, in the study, a comprehensive literature review was conducted, while secondary data from various sources were included, and thoughts and events affecting the security perceptions of the periods were handled with an interpretative perspective.

\section{Kaynakça / References}

Acar, C. (1991). Soğuk savaş süpergüçlerin hakimiyet kavgası, İstanbul: Ötüken Neşriyat.

Akçay, E. ve Akbal, Ö. (2013). ABD Güvenlik politikasında söylem ve pratik. Yönetim Bilimleri Dergisi, 11(22), 7-29.

Amanov, Ş. (2007). Sovyetler Birliği'nin dağglmasından sonra Amerika Birleşik Devletleri'nin Orta Asya politikası. Yayınlanmamış Doktora Tezi. Gazi Üniversitesi Sosyal Bilimler Enstitüsü Uluslararası İlişkiler Anabilim Dalı, Ankara.

Arı, T. (2004). Irak, İran ve ABD: Önleyici savaş, petrol ve hegemonya. İstanbul: Alfa Yayınları.

Armaoğlu, F. (2010). 19. Yüzyıl siyasi tarihi, 6. Basım, İstanbul: Alkım Yayınevi.

Arsan, O. ve Arı, S. (2004). Amerika özgürlük havarisi mi?, Ankara: Plan Yayınları.

Ataöv, T. (2003). 11 Eylül: Terörle savaş mı bahane mi, İstanbul: Alkım Yayınları. Ateş, T. (2004). ABD Dış politikasında yeni yönelimler ve dünya, Ankara: Ümit Yayınları.

Avaner, T. ve Çiner, C. U. (2019). Karşılaştırmalı iç güvenlik yönetimine giriş: Ülke örnekleri, Ankara: Gazi Kitabevi.

Bilensoy, İ. (2018). George W. Bush ve Barack Obama dönemlerinde terörizme karşı uygulanan politikaların karşılaştırılması, Lectio Socialis, 2(1), 5073.

Billington, R. A. (1961). American History since 1865 with questions and answers, New Jersey: Adams and Co.

Caldwell, D. (2011). Vortex of conflict: U.S. policy towards Afganistan, Pakistan and Iraq, California: Stanford University Press.

Canbolat, İ. S. (2003). Savaş ve barış arasında Dünya, Bursa: Alfa Yayınları. 
COMH (1989). American military history. Washington: Center of Military History United States Army,

Çakmak, H. (2003). Avrupa güvenliği, (2. Basım), Ankara: Akçağ Yayınları.

Çimen, H. (2007). Amerika'nın Irak'a müdahalesi sonrası yaşanan gelişmelerin Türk-Amerikan ilişkilerine etkisi. Yayınlanmamış Yüksek Lisans Tezi. Kırıkkale Üniversitesi Sosyal Bilimler Enstitüsü Uluslararası İlişkiler Anabilim Dalı, Kırıkkale.

Dabanlı, İ. T. (2007). 11 Eylül sonrası ortamda (2001 - 2003) ABD Milli güvenlik stratejilerinin Türkiye Cumhuriyeti milli güvenlik stratejilerine etkileri. Yayınlanmamış Doktora Tezi. Gazi Üniversitesi Sosyal Bilimler Enstitüsü Tarih Ana Bilim Dalı, Ankara.

Dumbell, J. (1995). The Carter Presidency: A Re-Evaluation, Manchester: Manchester University Press.

Erhan, Ç. (2002). ABD ve NATO'yla ilişkiler 1945-1960. (B. Oran Der.), Türk Dış Politikası, Kurtuluş Savaşından bugüne olgular, belgeler, yorumlar(1919-1980) içinde., Ankara: İletişim Yayınları.

Erhan, Ç. (2003). ABD'nin Orta Asya politikası ve 11 Eylül sonrası yeni aç1lımları, Strateji ve Analiz Dergisi, 9, 1-21.

Erkmen, S. (2001). 11 Eylül 2001: Terörizmin yeni miladı, Stratejik Analiz. 2(18), 5-16.

Ermağan, İ. (2012). Soğuk Savaş sonrası dönemde ABD Dış Politikası - Obama dönemi ve Ak parti, Elektronik Siyaset Bilimi Araştırmaları Dergisi, 3(2), 21-35.

Eroğlu, C. (2016). Çă̆daş devlet düzenleri, Ankara: İmaj Yayıncılık.

Ersun, Ö. (1984). Nükleer çağda NATO savunma stratejisi ve nükleer denge, NATO Savunma ve Eğitim Yönleri Sempozyumu, 5-6 Ocak 1984, Ankara: Ankara Üniversitesi Basımevi, 21-33.

Fischer, J. (2005). Tarihin dönüşü, İstanbul: Merkez Kitapları.

Fry, M. G., Goldstein, E. ve Langhorne, R. (2002). Guide to international relations and diplomacy, New York: Continuum.

Ganley, A. C., Lyons, T. T. ve Sewall, G. T. (1985). After Hiroshima America since 1945, New Hampshire:The Independent School Press.

Gezici, A. (2009). Barack Obama türkiye konuşmaları, İstanbul: Karakutu Yayınlar1.

Gohlert, E. W. (1974). National security policy formation in comparative perspective, Policy Studies Journal, 3(2), 174-177. 
Göçoğlu, V. (2018). Türkiye'nin siber güvenlik politikalarının kamu politikası analizi çerçevesinde değerlendirilmesi. Yayınlanmamış Doktora Tezi. Hacettepe Üniversitesi, Sosyal Bilimler Enstitüsü, Ankara.

Gürkaynak, M. (2008). Amerika Birleşik Devletleri ile NATO arasındaki simbiotik ilişki ve bu ilişkinin geleceği, ( E. Embel Der), Prof. Dr. Fahir Armaoglu'na armağan içinde (s.553-607), Ankara: Türk Tarih Kurumu Yayınları.

Gürses, E. (2003). ABD dış politikasında realizm ve idealizm, Jeopolitik Dergisi, 7, 47-50.

Hastedt, G. P. (1991). American Foreighn policy past, present, future, New Jersey: Prentice Hall Inc..

Jafarov, S. (2007). Dünden bugüne Rusya-NATO ilişkileri, İstanbul: Ezgi Kitabevi.

Kavuncu, S. (2013). Nükleer silahsizlanma yolunda start süreci, Bilge Strateji, 5(8), 119-148.

Kayar, M. (2003). Türk Amerikan İlişkilerinde Irak Sorunu, İstanbul: Kültür Sanat Yayınları.

Keskin, M. (2016). ABD'nin müdahaleci dış politikası: Latin Amerika örneği, Barış Araştırmaları ve Çatı̧̧ma Çözümleri Dergisi, 4(1), 70-88.

Kissinger, H. (2000). Diplomasi, (Çev. İ. H. Kurt), Ankara: İş Bankası Kültür Yayınları.

Kurat, A. N. (1964). Başkan Lyndon B. Johnson ve ABD'de cumhurbaşkanlı̆̆̆, Ankara: Dost Yayınları.

Lehman, J. ve Willett, T. D. (1986). National security and industrial policy: The Need for a public choice perspective, Contemporary Policy Issues, 7, 3647.

Lind, M. (2006). The American Way of strategy: U.S. Foreign policy and the American way of life, NY: Oxford Universtiy Press.

Meiertöns, H. (2010). The Doctrines of US security policy: An evaluation under international law, New York: Cambridge University Press.

Neumann, C. E. (2018). Kennedy administration (1961-1963), United States National Security Policy. 16.12.2018 tarihinde şuaradan ulaşılmıştır, http://www.faqs.org/espionage/Int-Ke/Kennedy-Administration1961- 1963-United-States-National-Security-Policy.html/,

Nevins, A. ve Commager, H. S. (2014). ABD tarihi, (Çev. H. İnalcık), Ankara: Doğu Batı Yayıncılık. 
Orme, J. M. (1983). The Military as an of U.S policy in Southwest Asia, The Rapid deployment fast force 1979-1982, Colorado: Westview Pres.

Özeren, S., Cinoğlu H. ve Sever, M. (2010). ABD'nin Afganistan ve Irak'ta terörle mücadele politikası, Ankara: UTSAM Raporlar Serisi: 14.

Öztürk, M. (2002). ABD’nin Yeni ulusal güvenlik stratejisi küresel ölçekte kaotik bir ortamin habercisi gibi, 2023 Dergisi, 19, 16-21.

Rosenberg, N. R. ve Rosenberg, E. S.(1987). In our times America since World War II, New Jersey: Prentice Hall Inc.

Sadioğlu, U. ve Erdinçler, E. (2018). Tarihsel perspektiften geleceğe, yerel yönetimler bağlamında Rus Kamu yönetiminde güncel reformların analizi, Memleket Siyaset Yönetim, 13(29), 61-82.

Sander, O. (1979). Türk-Amerikan ilişkileri 1947-1964, Ankara: Siyasal Bilgiler Fakültesi Yayınları.

Sander, O. (1991). Siyasi tarih 1918-1990, Ankara: İmge Kitabevi.

Sander, O. (1995), Siyasi tarih 1919-1994, İkinci Basım, Ankara: İmge Kitabevi.

Schulzinger, R. D. (1990). American diplomacy in the twentieth century, New York: Oxford University Press.

Seren, M. (2018). ABD ulusal güvenlik strateji belgesi: Amerikan savunması ve caydırıcılığı, Trend Analizi Thinktech STM Teknolojik Düşünce Merkezi, Şubat 2018.

Sönmezoğlu, F. (2005). Uluslararası politika ve dış politika analizi, İstanbul: Filiz Kitabevi.

Sümer, G. (2008). Amerikan dış politikasının kökenleri ve Amerikan dış politik kültürü, Uluslararası İlişkiler, 5(19), 119-144.

Şişman, B. (2015). Soğuk savaş dönemi ABD'nin değişen güvenlik politikası ve bu politika çerçevesinde ABD-Japonya ilişkileri. Yayınlanmamış Yüksek Lisans Tezi. Kocaeli Üniversitesi Sosyal Bilimler Enstitüsü Uluslararası İlişkiler Anabilim Dalı, Kocaeli.

The White House (2002). The national security strategy of the United States of America, 17.12.2018 tarihinde şuradan alınmıştır: https://www.state.gov/documents/organization/63562.pdf

The White House, (2006), The national security strategy of The United States of America, 17.12.2018 tarihinde şuradan alınmıştır: https://www.state.gov/documents/organization/64884.pdf

The White House, (2010), The national security strategy of The United States of America, 18.12.2018 tarihinde şuradan alınmıştır: http://nssarchive.us/NSSR/2010.pdf 
The White House, (2017), The national security strategy of the United States of America, 18.12.2018 tarihinde şuradan alınmıştır: https:/www.whitehouse.gov/wp-content/uploads/2017/12/NSS-Final-12-18-2017-0905.pdf

Toman, M. ve Akman H. (2014). Tarihi süreç içerisinde Amerikan İmparatorluğu, Tarih Okulu Dergisi (TOD), 7(20), 285-331.

Turan, İ. (1971). NATO ittifakının stratejik ve siyasi sorunları, İstanbul: Çağlayan Basımevi.

Uçarol, R. (2008). Siyasi tarih [1789-2001], İstanbul: Der Yayınları.

United States Of America Office of The Historian, (2018). Central America, 1981-1993, 17.12.2018 tarihinde şuradan alınmıştır: https://history.state.gov/milestones/1981-1988/central-america, (E.T. 17 Aralık 2018).

United States Of America Office of The Historian, (2018). Fall of communism in Eastern Europe, 1989, 17.12.2018 tarihinde şuradan alınmıştır: https://history.state.gov/milestones/1989-1992/fall-of-communism

United States of America Department Office of The Historian, (2018). Kennedy's foreign policy, 16.12.2018 tarihinde şuradan alınmıştır: https://history.state.gov/departmenthistory/short-history/jfk-foreignpolicy/

United States of America Department Office of The Historian, (2018). U.S. Soviet relations, 1981-1991, 17.12.2018 tarihinde şuradan alınmıştır: https://history.state.gov/milestones/1981-1988/u.s.-soviet-relations

United States Of America Office of The Historian, (2018), The collapse of the Soviet Union, 17.12.2018 tarihinde şuradan alınmıştır: https://history.state.gov/milestones/1989-1992/collapse-soviet-union

United States Of America Office of The Historian, (2018), The Suez Crisis, 1956, 15.12.2018 tarihinde şuradan alınmıştır: https://history.state.gov/milestones/1953-1960/suez/

Urul, A. (2008). Amerika Birleşik Devletleri'nin büyük Ortadoğu projesi ve Türkiye. Yayınlanmamış Doktora Tezi. Marmara Üniversitesi Sosyal Bilimler Enstitüsü Kamu Yönetimi Anabilim Dalı, İstanbul.

Uzgel, İ. (2002). ABD ve NATO ile ilişkiler, (B. Oran Der.), Türk Dış politikası, Kurtuluş Savaşından bugüne olgular, belgeler, yorumlar, içinde(s.243259), İstanbul: İletişim Yayınları. 
Üstün, K. (2018). Trump döneminde ABD yalnızlaşıyor, SETAV, 18.12.2018 tarihinde şuradan alınmıştır: https://www.setav.org/trump-donemindeabd-yalnizlasiyor/

Yalçın, H. B. ve İlhan, B. (2017). Trump'lı ABD'nin muhtemel dış politika ve güvenlik stratejisi, Analiz, 178.

Yeşilbursa, B. K. (2002). İngiltere'nin ortadoğu savunma projeleri ve Türkiye'nin NATO'ya Girişi, (1950-1953)", Türkiye'nin Güvenliği Sempozyumu: Tarihten Günümüze İç ve Dış Tehditler, 17-19 Ekim, 2001, Elazığ: Ceren Matbaası.

\section{Kaynakça Bilgisi / Citation Information}

Gündüz, O. ve Göçoğlu, V. (2020). Ulusal güvenlik politikası çerçevesinde ABD'nin güvenlik anlayışına kronolojik bir bakış. OPUSUluslararası Toplum Araştırmaları Dergisi, 15(21), 725-755. DOI: 10.26466/opus.629941 